\title{
Validity of learning devices based on guided discovery learning model
}

\author{
Meisa Kurnia ${ }^{1}$, Irwan' ${ }^{2}$, Yerizon ${ }^{3}$ \\ ${ }^{123}$ Universitas Negeri Padang, Padang - Indonesia, (meisakurnia9@gmail.com)
}

\begin{abstract}
One of mathematics learning purposes for students is having the capability or skill to solve a mathematics' problem, as a means for students to sharpen accuracy, logical, critical, analitycal, and creative reasoning so that problem was not a problem anymore for students. For optimal learning process, it is necessary supported by relevant learning device. This is the basis for research in mathematics learning device development like lesson plan and students worksheet based on Guided Discovery Learning model where learners are also learning and thinking to solve their problems independently through the materials facilitated by teachers and teacher's guidance. This was a development research which applied Plomp model. Based on the result of research, it could be concluded that guided discovery learning was valid.
\end{abstract}

Keywords: learning device, guided discovery learning

This is an open access article distributed under the Creative Commons 4.0 Attribution License, which permits unrestricted use, distribution, and reproduction in any medium, provided the original work is properly cited. (O2018 by author and Faculty of education, Universitas Negeri Padang.

\section{Introduction}

Mathematics as one of the subjects in school plays an important role because the purpose of learning mathematics is the formation of thinking ability of learners. The thinking ability of the learners is reflected through mathematical abilities that are useful for solving a daily problem both in the field of mathematics and other fields.

The Regulation of Ministry of Education and Culture (Peraturan Menteri Pendidikan dan Kebudayaan / Permendikbud) explained that the subjects of mathematics are studied with the same purpose that learners have the ability to think critically, logically, analytically, and creatively, problem solving ability, comprehension of mathematical concepts, explain the interconnection of concept flexibly, accurately efficient and precise in troubleshooting; develop an attitude of appreciating mathematics in life, which has a curiosity, attention, and interest in learning mathematics, as well as a tenacious attitude and confidence in solving problems in everyday life. The result of studying mathematics that learners are expected to have a creative personality, critical, scientific thinking, honest, frugal, disciplined, diligent, humane, have feelings of justice, and responsible.

One of the important mathematical skills to be achieved by learners in learning mathematics is the ability problem-solving. Troubleshooting is the process used to solve a problem. Problem solving in mathematics includes the process of finding answers to a question that requires procedures or steps that are not routine and contained in a form of text, non-routine puzzles and situations in real life. 
If learners are trained to solve problems, learners will be able to make decisions, because learners have become skilled about how to gather relevant information, analyze information, and realize how it is necessary to re-examine the results that have been obtained. Paying attention to what learners will gain by learning to solve problems, it is natural that problem solving is a very important, even the most important part of learning math.

The ability of learners to solve problem solving is still low. This authors find the field based on observations and interviews conducted in SMPN 24 Padang (Junior High School 24 Padang), found the results that the problem-solving ability test is still low. This data was obtained when the author gave 2 pieces of test questions to 28 students to see the ability of problem solving mathematical learners. The average score of the obtained classes is 6.96 from the ideal score of 20. It can be concluded that in solving the problem solving problem $65.2 \%$ of the students' answers are not accurate and this needs to be overcome.

The ability of problem solving learners that have not been optimal is caused by several things, such as the lack of maximum learning process in the classroom because the learning is still centered on the teacher so that students are not optimal in constructing their own knowledge.

The results of questionnaires given to learners, found that most of the learners are still rarely involved in solving problems given by the teacher. Most learners also rarely collect information based on teacher-provided problems. Based on the interview with the teacher of mathematics teacher at SMPN 24 Padang, found the problem that learners are still difficult in understanding the subject matter because students rarely repeat the lessons that have been learned. According to the teacher, the learners have been able to identify the elements that are known and asked, but to choose a strategy and perform calculations in answering the problem, most learners are still wrong. Another problem that is found is the learning device used by teachers is still not complete. No teachers have created their own LKPD (Student Worksheets) for student use.

In an effort to improve the problem solving skills of learners and overcome the above problems, one way that teachers can use is to develop learning devices based on Guided Discovery Learning model. Guided Discovery Learning model is a learning model that requires learners to organize their own way of learning in finding the concept of a learning material. This is in accordance with Permendikbud [1], the principles of the competency standards of graduates and the standard of instruction content on point one is the learning used "from learners who are told, to learners who find out"

According to Markaban [2] Learning with discovery is important because learners can actively participate in learning, fostering as well as inculcating inquiry (find-out) attitudes, supporting problem solving skills of learners, providing a means of interaction between learners and learners with teachers and materials the learned can achieve high capabilities and longer imprints because learners are involved in the learning process. This is reinforced by the statement of Khomsiatun [3] that learning with discovery results lasts long in learners' memory because learners are directly involved in the process of knowledge formation through experience. In addition, learners become accustomed to face problems and try to find a solution.

\section{Method}

The development model applied in this research is the Plomp model consisting of three phases, namely preliminary research, development or prototype phase, and assessment phase [4]. Stages used are up to the prototype 2 , that is the stage expert review.

In the preliminary analysis, curriculum review, concept analysis and learner analysis were conducted. Needs analysis was done by collecting the required information from the development of 
learning tools such as observation of the learning process, teacher interviews, giving questionnaires and problem-solving skills tests to learners.

At phase Prototyping phase, making of prototype was done through formative evaluation. After the device was designed, it is called prototype 1. Prototype 1 is then done self evaluation and expert review which produce prototype 2 . The research data was collected through validation sheet. Validation of learning device was done by lecturer of mathematics, lecturer of language and lecturer of education technology.

\section{Results and Discussion}

At the stage Preliminary Research conducted need analysis, curriculum analysis, concept analysis. And analysis of learners. At need analysis, the collection of information about the mathematical problems contained in mathematics learning was done. Activities undertaken were observations of the learning process in the classroom and learning outcomes, as well as interviewing teachers of mathematics.

The problem seen is the learning tools used by teachers is still not complete. Teachers have not yet developed their own LKPD for use by learners. RPP (Rencana Pelaksanaan Pembelajaran / Lesson Plans) made by the teacher looks good enough and already refers to the standard learning process, only RPP can be developed again in the main activities that is through the steps or learning activities that can lead learners to use the ability to solve mathematical problems in daily life problem which can construct the knowledge they possess.

The curriculum analysis was conducted by reviewing the 2013 curriculum for the mathematics class VII of SMP / MTs in the first semester. The results of this analysis are used as reference in the translation of Basic Competency, indicators of competency achievement and the allocation of learning time to achieve the learning objectives.

Concept analysis aims to determine the content and subject matter needed in the development of learning tools. The lesson materials in the first semester are Numbers (Integer and Fractional Numbers), Set, Algebraic Form, and Equations and Linear Inequalities One Variable.

Through the results of interviews with teachers, the information which was obtained was that grade VII students in SMPN 24 Padang has varying academic abilities, including high ability, moderate and low. In general, students who sit in grade VII have the age of 13-14 years. According to Piaget's cognitive development theory, they are in the formal operational phase with the basic characteristics of their development already capable of thinking abstractly, logically, drawing conclusions, interpreting and developing hypotheses. However, in reality learners are still not able to construct their own knowledge because learning is still centered on the teacher.

1. Student questionnaire results indicate that the character of learners prefer learning activities in groups. Thus, the process of learning-aided learning media is done in groups and most learners have planned all activities in doing group work

2. Based on the questionnaire, the dominant learners choose the blue color for their favorite color. This color gives a lot of positive influence on the psychological readers. This is in accordance with Eisman's opinion (in Syamsuddin, 2014) which states that the blue color has the meaning of honesty, tranquility, loyalty, dependability, harmony, giving the impression of roomy and sensitive. So blue color is chosen as the dominant color for LKPD's specialized learning device.

Next, Designing a Guided Discovery Learning based mathematical learning tool based on analysis in the preliminary analysis phase. 


\section{Designing RPP (Lesson Plan)}

RPP was developed with reference to Permendikbud No. 22 year 2016 on The Standards Process that presents the components which must exist in the RPP include school identity, subject identity, class / semester, subject matter, time allocation, learning objectives, competency standards or indicators of achievement of competencies, learning materials, methods learning, learning media, learning resources, learning steps and assessment of learning outcomes.

In general, the learning activities consist of three activities, namely preliminary activities, main activities and closing activity. Preliminary activities include the delivery of learning objectives, motivation and apperception. The main activity is an activity that includes the steps of the guided discovery learning model that includes stimulus, problem statement, data collection, data processing, verification, and generalization ( conclusion). Meanwhile, closing activities include reflecting on the learning process, as well as the delivery of material for subsequent meetings.

\section{Designing LKPD (Student Worksheets)}

LKPD is developed by taking into account the criteria of the guided discovery learning model process with the provision of stimuli at the beginning of the learning process and taking into account the skills of learners in solving the problem. The types of writing used in the preparation of LKPD are Comic Sans MS and Franklin Gothic Heavy. This type of writing is used because it is in accordance with the characteristics of writing favored by learners. The size of the letters used ranges from 12 to 18. Colors in LKPD are dominated by blue with a pink combination.

Presentation on LKPD contains introduction, table of contents, Main Competence and Basic Competence (KD), competency achievement indicators, LKPD usage guidelines, learner activities, training questions, and referral lists.

LKPD has interesting pictures, according to the problem to be solved. LKPD begins with the provision of stimulus at the beginning of the learning process and pay attention to the skills of learners in solving problems.

LKPD uses a simple and communicative language and in accordance with the level of communication grade VII Junior High School. The statements and orders contained in LKPD are arranged with clear sentences so as to direct learners to gain meaning from the material they are studying. The cover page contains the identity or title of LKPD based on Guided Discovery Learning.

The design result of RPP and LKPD is called prototype I. This prototype is then evaluated by themselves and assessed by experts.

1. Self-evaluation

The self-evaluation is done by looking back at the design result of the device and fixing the obvious errors on the device, such as mistyping, word usage, terms, punctuation, and image placement. Furthermore, there are several key aspects evaluated, namely: the suitability of RPP elements, the suitability of the content / learning materials, the suitability of RPP and LKPD based on guided discovery lerning. In general, many errors occur in the use of punctuation and typing errors. In the RPP there are typographical errors, such as lack of letters in a word and errors in the use of spaces and the use of capital letters at the beginning of the sentence.

In LKPD there is an error in typing and using spaces, like the word "picture" written "pictuure", the word "equation" written "equaation". Furthermore, there are errors in the use of punctuation, such as the use of exclamation marks for the command line in the problem instructions and inconsistent use of the word "Ananda (you in a more polite way" as a greeting to learners, because in some parts of the LKPD written using the word "Kamu (you in general)".

After a self-evaluation revision of the errors were made, then the revised results were consulted and discussed with experts or experts and validated. 


\section{Expert Review}

The guided discovery learning based mathematics learning device was validated by five experts (validators). Validators involved in the validation process were mathematics education experts, language experts and educational technology experts.

RPP validation was done by four validators consisting of three mathematics educators and one language expert. Prior to being validated, some parts of the RPP have improved or revised according to the suggestions of the validator. Here are suggestions from validators for RPP: (1) RPP format should be written based on the latest Permendikbud. (2) In the Lesson Subject section there is a wrong word, once again pay attention in writing. (3) Fix the sentence on preliminary activity point no 4 . (4) Notice the beginning of sentences and punctuation, adjusting with Indonesian Spelling.

After correction to RPP in accordance with the suggestion validator, then RPP is discussed once again with validator until a valid RPP is obtained. The results of RPP validation can be seen in Table 1.

Table 1. Results of RPP Validation

\begin{tabular}{|c|c|}
\hline Aspect of the Assessed & Validity Index \\
\hline Identity Aspect of RPP & 0,97 \\
\hline Aspects of Learning Activities & 0,97 \\
\hline Language Aspect & 0,83 \\
\hline Total & 2,77 \\
\hline Validity Index & 0,92 \\
\hline Criteria & Valid \\
\hline
\end{tabular}

From Table 1, it can be concluded that the overall RPP-based guided discovery learning model meets the valid criteria with the validity index of 0.92 .

The LKPD validation is performed by five validators consisting of three lecturers of Mathematics Education to validate aspects of presentation and content aspects, one lecturer of Educational Technology to validate the display aspect and one lecturer Language to validate the language aspect. Prior to being validated, some parts of LKPD have improved or revised based on suggestions from validators. Here are suggestions from validators for the improvements: (1) Improve the look on the cover and contents of LKPD. (1) Improve the Competency Achievement Indicators. (1) The imperative sentence and writing must be according to Indonesian Spelling.

After the improvement of LKPD in accordance with the suggestion of the validator, then LKPD rediscussed with validator until a valid LKPD is obtained. LKPD validation results can be seen in Table 2.

Table 2. LKPD Validation Results

\begin{tabular}{cc}
\hline Aspect of the Assessed & Validity Index \\
\hline Presentation Aspect & 0,93 \\
Eligibility Aspect Content & 0,95 \\
Display Aspect & 0,67 \\
Language Aspect & 0,83 \\
Total & 3.38 \\
Validity Index & 0,85 \\
Criteria & Valid \\
\hline
\end{tabular}

Based on Table 2, it can be concluded that the overall LKPD-based guided discovery learning model meets the valid criteria with the validity index of 0.85 .Validation results imply that LKPD is in 
accordance with the competence to be achieved. Activity step has been formulated based on guided discovery learning model so that it facilitates learners in learning, besides learners can also apply it for problem solving.

\section{Conclusions}

Based on the results of data analysis carried out, it can be concluded that learning device based on guided discovery learning model designed has been valid and can be used for students in grade VII, in SMP / MTs. Based on the conclusion, the learning device based on guided discovery learning model can be used as a guideline for teachers in implementing learning.

\section{Acknowledgments}

The authors wish to thank Dr. Irwan, M.Si and Dr. Yerizon, M. Si as a supervisor and lecturers of Universitas Negeri Padang who has given guidance and direction sincerely and patient in the making of this article. This article is based on a thesis written by Meisa Kurnia entitled "Development of Learning Devices Based on Guided Discovery Learning Model to Improve Problem-solving Ability of Students Class VII in SMP / MTs".

\section{References}

Kemdikbud. (2014). Peraturan Menteri Pendidikan dan Kebudayaan Nomor 58 Tahun 2014 tentang Kurikulum 2013 SMP/MTs. Jakarta: Kemdikbud.

Markaban. (2008). Model Penemuan Terbimbing pada Pembelajaran Matematika SMK. Yogyakarta : Pusat Pengembangan dan Pemberdayaan Pendidik dan Tenaga Kependidikan Matematika.

Khomsiatun, Siwi dan Heri Retnawati. (2015). Pengembangan Perangkat Pembelajaran dengan Penemuan Terbimbing untuk Meningkatkan Kemampuan Pemecahan Masalah. Jurnal Riset Pendidikan Matematika Volume 2 - Nomor 1, Mei 2015 (92-106). ISSN : 2356-2684.

Plomp, T and Nieveen, N. (2013). An Introduction to Educational Design Research. Enschede: Netherland Institute for Curriculum Development (SLO) 